\title{
Pengembangan Perangkat Pembelajaran PPKn Berbasis Model Predict, Observe, Explain (POE) dalam Meningkatkan Keterampilan Berpikir Kritis dan Pemahaman Konsep Siswa Kelas V Sekolah Dasar
}

\author{
${ }^{1}$ Dimas Aditya Nugroho, ${ }^{2}$ Mustaji, ${ }^{3}$ Raden Roro Nanik Setyowati \\ ${ }^{123}$ Universitas Negeri Surabaya \\ Email: Dimasaditya.18029@mhs.unesa.ac.id
}

\begin{abstract}
This research aims to describe the results of the validity, practicality of learning devices, and the effectiveness of the integrated learning tools of the POE model to help student understanding of concept and famililiarize students with critical thinking skills. This research isa research development that adapting using a 4-D development model and data collection techniques using observations, questionnaires, and test. The trial was conducted in the 2019/2020 school year with a total of 20 research subjects. The results of the research that have been done prove that the POE model based learning process can be applied because it has good validity with an average value above 3.6, while for the evaluation of practicability it can be said to be weel proven in the implementation of learning which has an average have value of $79,5 \%$, and the effectiveness of the learning process can be agreed affective based on the learning achievement test related to understanding concept and critical thinking skills before only $45 \%$ of students who completed it and after participating in learning up to $100 \%$ of students who completed it resulted with a value of $\geq 75$.
\end{abstract}

Keywords: Predict, Observe, Explain (POE) Models, Concept Understanding, and Critical Thinking Skills

\section{Pendahuluan}

Pembelajaran merupakan sesuatu yang penting bagi siswa karena pembelajaran bertujuan untuk membentuk kepribadian dan pemikinan dari sekolah siswa sehingga terjadi terjadi perubahan yang positif, Menurut Haryono pembelajaran yang dilakukan merupakan proses penyampaian informasi dan pengetahuan lainnya yang dilakukan oleh guru kepada murid dengan tujuan agar siswa dapat mengembangkan potensi diri sehingga dapat berguna dikemudian hari. Tujuan pembelajaan akan tercapai apabila guru mempertimbangkan proses pembelajaran yang meliputi proses pemberian materi, penyusunan materi, dan pengaturan suasana kelas sehingga pembelajaran akan lebih efektif dan bermakna. Salah satu pembelajaran yang harus ada pada jenjang sekolah dasar yaitu pembelajaran PPKn, karena pembelajaran tersebut memiliki tujuan agar siswa mempunyai rasa kebangsaan yang tinggi dan memiliki budi pekerti luhur yang baik sehingga menjadi warganegara yang baik. ${ }^{1}$

Pembelajaran PPKn di sekolah dasar dijadikan sebagai sarana agar siswa mempunyai rasa cinta terhadap tanah air, bertanggung jawab, bernilai luhur, dan berkarakter. Risvanelli pembelajaran PPKn disekolah bertujuan untuk menjadikan siswa agam memiliki rasa cinta terhadap tanah air dan memiliki kepridian yang baik. Selain itu juga tujuan pembelajaran PPKn diadakan pada sekolah dasar yaitu agar siswa dapat

1 Haryono, A. D. (2014). Metode Praktis Pengembangan Sumber Belajar dan Media Pembelajaran. Malang: Genius Media 
mengasah keterampilan berpikir kritis, dengan menyajikan materi-materi yang sering dijumpai oleh siswa dalam kesehariannya. ${ }^{2}$

Keterampilan berpikir kritis sangat baik untuk dikembangkan sejak dini karena kemampuan siswa untuk berpikir secara kritis terhadap segala sesuatu dapat membantu siswa dalam menganalisis persoalan dan menyelesaikannya dengan menggunakan pertimbangan yan tepat. Menurut Fisher kemampuan berpikir kritis melibatkan proses untuk menganalisis suatu informasi, ide, pendapat, dan konsep dengan mengajukan pertanyaan-pertanyaan sehingga siswa mendapatkan kesimpulan dari sebuah fakta dan pemikiran yang baik dalam menaggapi suatu informasi. Selain itu kemampuan untuk berpikir secara kritis dapat mempermudah siswa untuk mengolah suatu konsep mengenai materi pembelajaran yang diterima sehingga siswa memiliki pemahaman yang baik, karena berdasarkan pengertiannya kemampuan berpikir kritis yaitu kemampuan siswa dalam menganalisa suatu informasi yang ditemukan berdasarkan dengan menggunakan sumber-sumber yang relevan, oleh sebab itu penting untuk membiasakan siswa sejak dini untuk berpikir secara kritis terhadap segala sesuatu yaitu dengan cara guru menyajikan pembelajaran yang menarik bagi siswa dengan memberikan pertanyaan ataupun pernyataan yang bertujuan untuk mengajak siswa berpikir secara kritis serta sehingga pemahaman konsep mengenai materi yang disampaikan oleh guru dapat diterima oleh siswa. ${ }^{3}$

Proses pemahaman konsep yang dilakukan siswa dapat terbantu apabila siswa memiliki kemampuan untuk berpikir secara kritis. Pemahaman konsep memiliki pengertian yaitu pemahaman terhadap suatu ide, informasi, pengetahuan, dan fakta yang didapatkan oleh siswa saat melakukan pembelajaran. Menurut Sriyanti pemahaman konsep yaitu siswa dapat menerima dan memahami makna dari setiap informasi yang terima bukan hanya sekedar hafalan.

Salah satu upaya yang sebaiknya dilakukan dalam membantu siswa agar mimiliki pemahaman konsep yang yang baik yaitu dengan cara mengkondisikan suasana kelas dan pengkondisian proses pembelajaran agar lebih siswa lebih aktif dalam menemukan informasi yang. Pengelolaan proses pembelajaran dapat dikembangkan melalui rancangan terhadap proses pembelajaran yaitu dengan cara menentukan langkah-langkah yang digunakan pada saat pembelajaran dan menentukan model pembelajaran yang akan digunakan dengan mempertimbangkan kondisi lingkungan sekolah sehingga pembelajaran akan menjadi lebih efektif. ${ }^{4}$

Berdasarkan fakta yang diproleh pada saat melakukan observasi pada tanggal 2 Oktober 2019 menunjukkan bahwa proses kegiatan penyampaian materi kepada siswa belum dapat melatih siswa untuk berpikir secara kritis, hal tersebut disebabkan karenan

2 Risvanelli. (2017). Peningkatan Hasil Belajar dan Aktivitas Belajar Siswa Kelas V Menggunakan Pendekatan Value Clarification Technique (VCT) Pada Pembelajaran PKn di SDN 24 Batang Anai Kabupaten Padang Pariaman. Jurnal Penelitian Pendidikan Indonesia (JPPI). 3(2), 44-45. Doi: https://doi.org/10.29210//02017115.

${ }^{3}$ Fisher, Alec. (2009). Berpikir Kritis: Sebuah Pengantar. (Benyamin Hadinata, Penerjemah). UK: Cambridge University Press

4 Sriyanti. (2019). Upaya Meningkatkan Pemahaman Konsep Matematika Melalui Diskusi Kelompok Berbantuan Alat Peraga. Jurnal Pendidikan Matematika dan Ipa. 10(1). 63-73. Doi: 10.26418/Jpmipa.V10i1.2965 8 
penyampaian materi terhadap siswa hanya sebatas siswa mendengarkan penjelasan dari guru sehingga kurangnya interaksi timbal balik yang dilakukan oleh siswa dan guru menjadikan pembelajaran menjadi kurang interaktif. Selain itu pada salah satu komponen perangkat pembelajaran yang digunakan kurang invoatif dan hanya menggunakan model pembelajaran yang sama setiap pada setiap pembelajaran sehingga proses penyampaian materi menjadi kurang menarik. Pada dasarnya guru merupakan penentu keberhasilan siswa dalam mencapai tujuan dari pembelajaran yang telah ditetapkan. maka penentuan model menjadi hal yang sangat penting agar pembelajaran menjadi menarik dan efektif.

Perancangan model pembelajaran disesuaikan dengan tujuan-tujuan yang ingin dicapai sehingga pelaksanaan pembelajaran menjadi lebih efektif dan materi dapat tersampaikan dengan baik. Menurut Suprijono model pembelajaran merupakan gambaran dari kegiatan belajar secara keseluruhan dengan tujuan agar proses pembelajaran menjadi lebih efektif. Penggunaan model yang diterapkan dalam rancangan proses pembelajaran sangat membantu guru dalam meningkatkan kemampuan berpikir secara kritis dan kemampuan dalam pemahaman konsep yang dimiliki siswa, salah satu model pembelajaran yang baik untuk meningkatkan kemampuan berpikir kritis dan pemahaman konseps siswa yatu model POE karena model pada penerapannya lebih menekankan siswa agar lebih terlibat dengan aktif dalam proses untuk menemukan informasi, konsep, dan pengetahuan yang dicari dengan cara melakukan penyelidikan atau observasi yang dilakukan secara mandiri. ${ }^{5}$

Model pembelajaran Predict, Observe, Explain (POE) mempunyai kegiatan dalam proses pembelajarannya yang mengajak siswa untuk terlibat langsung dalam melakukan prediksi mengenai suatu fenomena dan membuktinya melalui observasi, dan menjelaskan hasil observasi yang telah dilakukannya.

Kala et al mengungkapkan bahwa model pembelajaran POE yaitu model yang melibatkan siswa untuk terlibat aktif pada proses pembelajaran dengan berdasarkan langkah-langkah kegiatan yang telah ditetukan yang meliputi kegiatan prediksi, observas, dan menjelaskan. Penggunaan model pembelajaran POE dalam proses pembelajaran PPKn sangat membantu siswa dalam mengambangkan kemampuan berpikir secara kritis dan dapat membantu siswa untuk mimiliki pemahaman konsep materi dengan baik. ${ }^{6}$

Berdasarkan pemaparan yang diuraikan di latar belakang maka penting untuk meneliti lebih dalam dan mengembangkan perangkat pembelajaran berbasis model POE guna meningkatkan kemampuan siswa dalam memahami konsep dan kemampuan untuk berpikir secara kritis. Penelitian tersebut dilakukan dengan menggunakan rumusan masalah yaitu 1) kevalidan, 2) Keperaktisan perangkat, dan 3) Keefektivan perangkat pembelajaran PPKn berbasis model POE untuk meningkatkan pemahaman konsep dan keterampilan berpikir kritis siswa kelas V sekolah dasar.

\footnotetext{
${ }^{5}$ Suprijono, Agus. (2016a). Model-Model Pembelajaran Emansipatoris. Yogyakarta: Pustaka Pelajar

${ }^{6}$ Kala, N., Yaman, F., \& Ayas, A. (2012). The Efeectiviness of Predict-Observe-Explain Technique in Probing Student' Understanding About Acid-Base Chemistry: pH, Poh, and Strength. International Journal of Science and Mathematics Education, 11(3), 555-574. Doi: 10.1007/s10763-012-9354-z
} 


\section{Metode Penelitian}

Penelitian yang dilakukan termasuk dalam penelitian pengembangan yang mengembangkan suatu perangkat pembelajaran terintegrasi model pembelajaran POE dalam meningkatkan kemampuan siswa dalam pemahaman konsep serta kemampuan untuk melakukan pemikiran secara kritis. Penelitian dilakukan di SD Negeri Lidah Kulon IV/467 Surabaya pada semester genap tahun ajaran 2019/2020, dengan menggunakan 20 orang siswa dari kelas $\mathrm{V}$ sebagai subjek penelitian.

Penelitian dilakukan menngunakan model pengembangan yang mengacu pada model pengembangan 4-D (four-D) dengan tahap definisi, desain, pengembangan, dan penyebaran. ${ }^{7}$ Desain penelitian ini yaitu one-group pretest-postest yang memiliki pengertian pemberian perlakuan terhadap 1 kelompok yang dijadikan subjek. Desain penelitian dapat digambarkan seperti berikut.

Tabel 1. Rancangan Uji Coba Perangkat Pembelajaran

\begin{tabular}{cccc}
\hline Kelas & Pretest & Perlakuan & Postest \\
\hline $\begin{array}{c}\text { Kelas uji } \\
\text { coba }\end{array}$ & $\mathrm{T}_{1}$ & $\mathrm{X}$ & $\mathrm{T}_{2}$ \\
\hline
\end{tabular}

(Adaptasi Sugiyono, 2015: 75)

Uji coba perangkat pembelajaran dapat dilakukan apabila telah dinyatakan layak oleh validator. Pada pelaksanaan penelitian, intrumen yang digunakan yaitu angket validasi, lembar pengamatan keterlaksanaan, lembar pengamatan aktivitas siswa, lembar angket terhadap respon siswa, lembar tes keterampilan berpikir kritis dan pemahaman konsep. $^{8}$

Data yang diperoleh setelah melakukan penelitian selanjutnya dianalisis dengan tujuan untuk melihat perangkat pemebalajaran layak atau tidak. Komponen pada perangkat pembelajaran yang telah dirancang dapat dikatakan layak apabila hasil rata-rata yang yang diperoleh telah memenuhi indikator yang ditetapkan sebagai berikut.

Tabel 2. Kriteria Kelayakan Perangkat Pembelajaran

\begin{tabular}{cc}
\hline Interval Skor & Kategori \\
\hline $3,6 \leq \mathrm{P} \leq 4,0$ & Sangat Valid \\
\hline $2,6 \leq \mathrm{P} \leq 3,5$ & Valid \\
\hline $1,6 \leq \mathrm{P} \leq 2,5$ & Kurang Valid \\
\hline $1,0 \leq \mathrm{P} \leq 1,5$ & Tidak Valid \\
\hline
\end{tabular}

Komponen-komponen dari perangkat pembelajaran yang sesuai dengan kriteria dan dinyatakan valid serta layak selanjutnya dapat diimplementasikan ke dalam pembelajaran yang ada di kelas agar dapat melihat keperaktisan dan kefektivan dari setiap komponen perangkat pembelajaran. Pada saat perangkat pembelajaran diterapkan

${ }^{7}$ Hobri. (2010). Metodologi Penelitian Pengembangan (Aplikasi Pada Penilitian Pendidikan Matematika). Jember: Pena Salsabila

${ }^{8}$ Sugiyono. (2015). Metode Penelitian Kuantitatif, Kualitatif, dan R\&D. Bandung: Alfabeta 
terdapat guru kelas yang mengamati dan menilai proses pembelajaran, guru yang melakukan pengamatan terhadap proses belajar ssiwa berjumlah 2 orang dan dari hasil penilaian pengamatan diperoleh data mengenai persentase keterlaksanaan pembelajaran sehingga data tersebut dapat dijadikan sebagai acuan mengenai keperaktisan. Data yang telah diperoleh lalu di analisi menggunakan rumus keterlaksaan pembelajaran sebagai berikut.

Keterangan:

$$
\mathrm{P}=\frac{\sum K}{\sum N} \times 100 \%
$$

P : Jumlah keseluruhan kegiatan yang keterlaksanaan (\%)

$\sum K \quad:$ Komponen kegiata yang telah terlaksana

$\sum N \quad:$ Keseluruhan dari komponen yang diamati

Data yang telah dianalisis selanjutnya diukur dengan menggunakan acuan atau kriteria yang telah ditetapkan untuk mengetahui persentase dan kategori keterlaksanaan komponen perangkat pembelaajaran, berikut kriteria penilaian.

Tabel 3. Kriteria Penilaian Keterlaksanaan

\begin{tabular}{cc}
\hline Interval Skor & Ketegori \\
\hline $100 \%-75 \%$ & Terlaksana dengan sangat baik \\
\hline $74 \%-50 \%$ & Terlaksana dengan baik \\
\hline $49 \%-25 \%$ & Kurang terlaksana dengan baik \\
\hline $24 \%-0 \%$ & Tidak Terlaksana \\
\hline
\end{tabular}

Kefektivan dari perangkat pembelajaran dapat ditentukan dari hasil nilai tes siswa sebelum melakukan pembelajaran dan setelah melakukan pembelajaran sehingga nanti terlibat perbedaan nilai pre-test dan post-test, jika nilai siswa setelah melakukan pembelajaran lebih tinggi dari sebelum pembelajaran maka dapat dikatakn perangkat pembelajaran efektif. Tes yang digunakan menggunakan 2 jenis soal yaitu soal tes pilihan ganda dengan jumlah 10 soal soal tes urian berjumlah 5 soal. Perhitungan kefektivan dilihat dati ketuntasan tes hasil belajar siswa secara individu dan klasikal jika terdapat $50 \%$ lebih siswa mendapatkan nilai diatas $K K M \geq 75$ maka dapat dikatakan efektif akan tetapi jika tidak terdapat perubahan sama sekali maka pembelajaran tidak efektif dan perlu dilakukan perbaikan. Data dari hasil tes siswa kemudian dianalisis menggunakan rumus berikut.

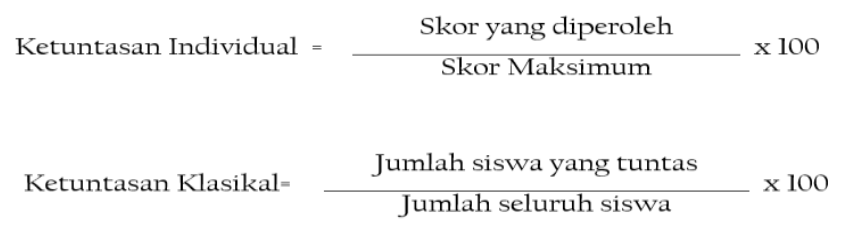

Setelah memperoleh data mengenai ketuntasan secara klasikan dan individu maka dilakukan perhitungan $N$-gain yang berfungsin untuk melihat perubahan kemampuan 
dari siswa sebelum mengikuti pembelajaran dan sesudah mengikuti pembelajaran, perhitungan $N$-gain dilakukan berdasarkan hasil nilai pre-test dan post-test. Perhitungan analisis $N$-gain menggunakan rumus sebagai berikut:

\begin{tabular}{|c|c|c|}
\hline & $N_{-}$ & $\left(S_{\text {post }}-S_{\text {pre }}\right)$ \\
\hline & & $\left(S_{\max }-S_{p r e}\right)$ \\
\hline 4 & & \\
\hline N-Gain & : Peningkatan & \\
\hline$S_{\text {post }}$ & : Skor tes setelah & lakukan pembelajaran \\
\hline$S_{p r e}$ & : Skor sebelum m & zukan pembelajaran \\
\hline$S_{\max }$ & : Skor maksimal & \\
\hline
\end{tabular}

(Sundayana, 2014: 151)

Data yang diperoleh dari hasil perhitungan pre-test dan post-test yang telah dianalisi menggunakan N-gain selanjutnya diukur berdasarkan kriteria-kriteria yang dijadikan acuan untuk meilihat peningkatan dari kemampuan siswa setelah mengikuti pembelajaran, sebagai berikut.

Tabel 4. Kriteria N-Gain yang Ternormalisasikan

(Adaptasi dari Sundayana, 2014: 151)

\begin{tabular}{cc}
\hline Interval Skor & Kategori \\
\hline$-1,00 \leq$ gain $<0,00$ & Terjadi penurunan \\
\hline gain $=0,00$ & Tidak terjadi peningkatan \\
\hline $0,00<$ gain $<0,30$ & Rendah \\
\hline $0,30 \leq$ gain $<0,70$ & Sedang \\
\hline $0,70 \leq$ gain $\leq 1,00$ & Tinggi
\end{tabular}

\section{Hasil dan Pembahasan}

Penelitian ini dilakukan untuk melihat seberapa valid komponen-komponen pembelajaran. Sedangkan keperaktisan dari perangkat pembelajaran dapat dilihat dari hasil keterlaksanaan RPP, aktivias siswa, dan respon siswa. Selain itu juga untuk melihat keefektivan perangkat pembelajaran menggunakan tolak ukur berdasarkan hasil tes pemahaman konsep dan tes keterampilan berpikir kritis.

Komponen pembelajaran sebelum diimplementasikan harus melewati tahap validasi dengan tujuan untuk melihat kelayakan dari perangkat pembelajaran. Proses penilaian kevalidan dilakukan dosen ahli yang bertindak sebagai validator, penilaian tersebut dilakukan dengan menggunakan instrumen angket validasi dengan penilaian berdasarkan kriteria-kriteria yang telah ditetapkan. Berikut ini hasil validasi yang telah dinilai oleh 2 orang validator. 
Dimas Aditya Nugroho, Mustaji, Raden Roro Nanik Setyowati, Pengembangan Perangkat

Gambar 1. Perhitungan Validitas Perangkat Pembelajaran

\section{Validitas Perangkat Pembelajaran}

3.8

3.75

3.75

\section{7} 3.7

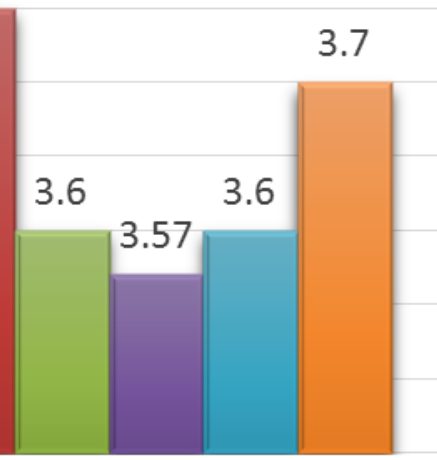

GPP

3.65
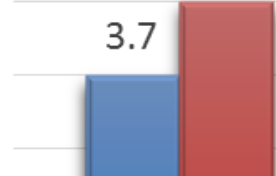

3.55

3.5

3.45

G Silabus

Bahan Ajar

日 LKS

Tes Pemahaman Konsep

Tes Keterampilan Berpikir Kritis

Berdasarkan data yang telah disebutkan diatas menggambarkan bahwa setiap komponen memiliki validan sangat baik dengan nilai terendah yaitu 3,57. Hal tersebut menjelaskan bahwa komponen dari perangkat pembelajaran yang dikembangkan telah layak untuk diterapakan pada proses pembelajaran dengan beberapa revisi kecil.

Keperaktisan dari perangkat pembelajaran dapat dilihat dari hasil penilaian terhadap keterlaksanaan RPP, aktivitas kegiatan siswa, dan respon siswa terhadap pembelajaran. Berikut ini penilaian keteraksanaan perangkat pembelajaran yang telah dilakukan selama 2 kali pertemuan.

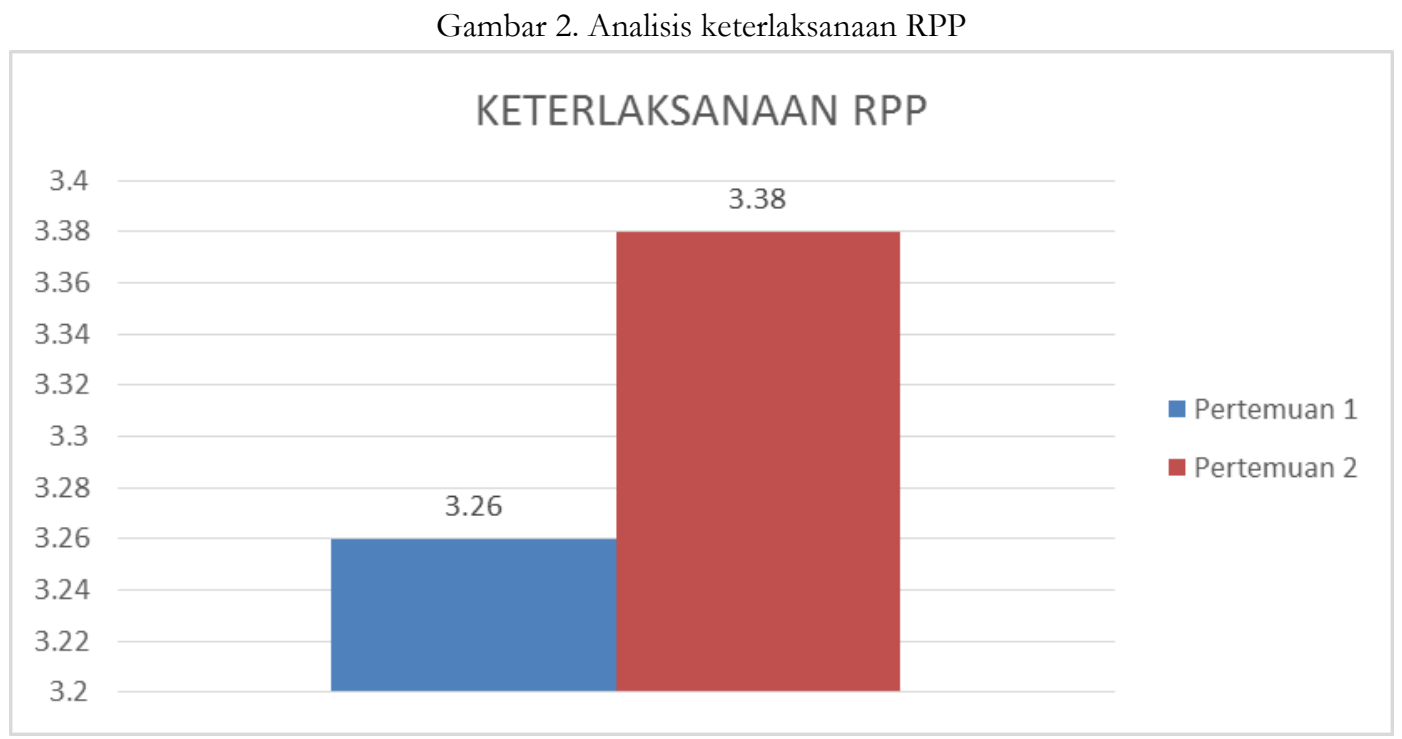

Data diatas menunjukkan bahwa RPP yang dirancang dapat terlaksana dengan baik, hal tersebut dibuktikan dari perolehan persentases pada pertemuan 1 dengan nilai rata-rata 3,26 atau sebesar 76\% hal tersebut menunjukkan bahwa RPP dapat terlaksana dengan baik, sedangkan pada pertemuan 2 keterlaksanaan RPP mengalami peningkatan menjadi 3,32 atau sebesar 83\% aspek pembelajaran terlaksana dengan sangat baik. Hasil 
persentase diperoleh dari penilaian guru yang berperan sebagai pengamat pembelajaran, sehingga dapat dikatakan data yang diproleh merupakan data lapangan yang valid, sehingga dapat disimpulkan bahwa proses pembelajaran yang terintergasi dengan model POE dapat terlaksana dengan baik pada siswa kelas $\mathrm{V}$.

Aktivitas siswa selama pembelajaran menujukkan hasil yang baik yaitu pada pertemuan 1 memilik kategori baik dengan persentase $67 \%$, sedangkan pada pertemua 2 memiliki kategori baik denga persentase 67,5\%. Penilaian aktivitas dilakukan unutk melihat seberapa aktis siswa selama mengikuti pembelajaran semakin aktif siswa maka pembelajaran yang dilakukan semakin baik karena sesuai konsep bahwa pembelajaran berbasis model POE merupakan model yang mengajak siswa untuk terlibat aktif dalam proses kegiatan pembelajaran. berikut gambaran dari penialian aktivitas siswa selama 2 pertemuan.

Gambar 3. Penilaian Aktivitas Siswa

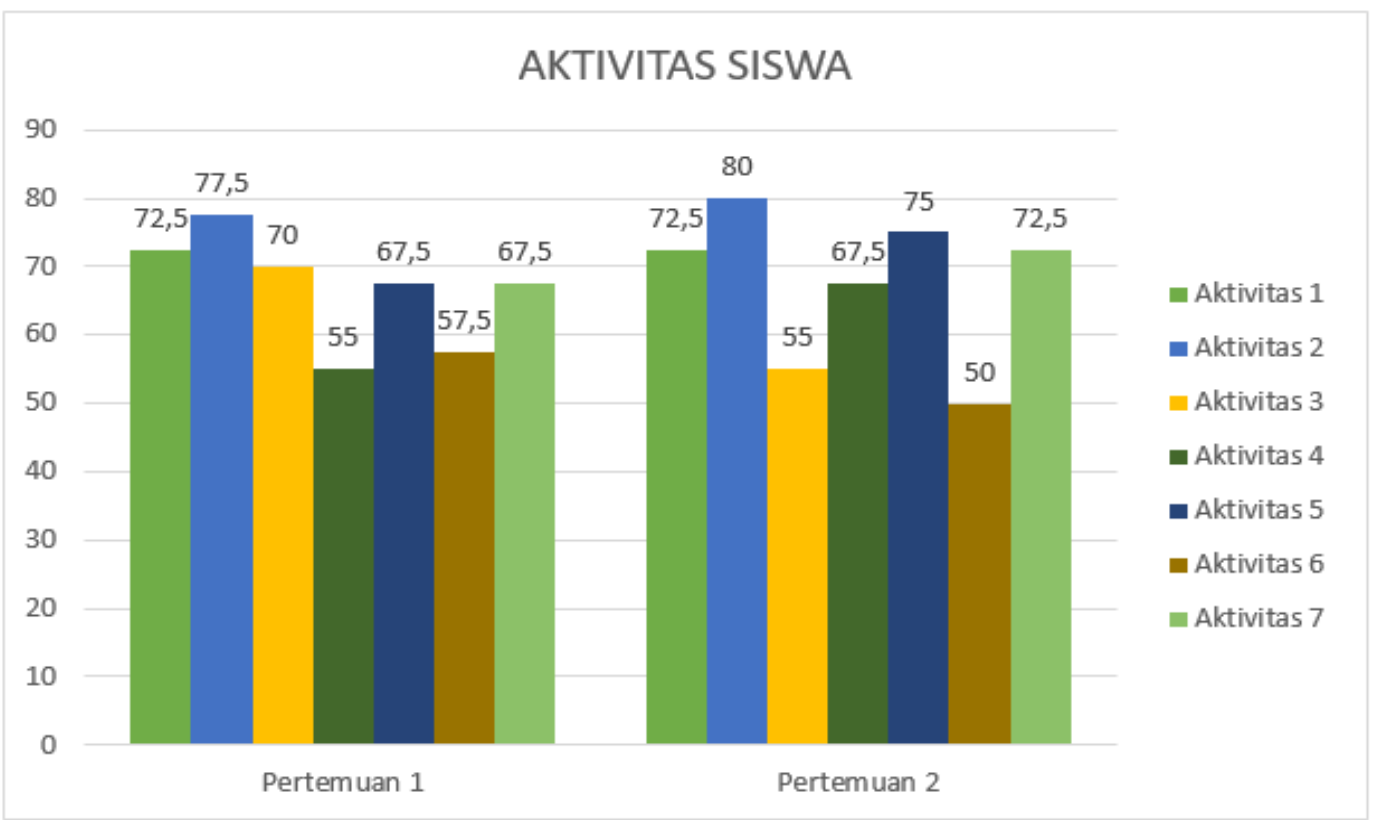

Berdasarkan data diatas menunjukkan penilaian yang positif sehingga dapat disimpulkan bahwa siswa aktif selain itu juga dengan hasil penilaian tersebut maka pembelajaran yang dilakukan terbilang menarik serta merangsang siswa untuk lebih aktif terlibat dalam kegiatan pembelajaran.

Sedangkan respon siswa terhadap pembelajaran yang telah dilakukan terbilang positif karena penilaian siswa terhadap proses pembelajaran memiliki persentase yag tinggi yaitu pada aspek ketertarikan siswa pada pembelajaran yang memiliki nilai persentase sebesar 90\% yang berarti penilaian tersebut menunjukkan bahwa pembelajaran yang dilakukan oleh siswa sangat menarik sehingga siswa memiliki antusias yang tinggi. Berikut ini data mengenai respon siswa. 
Gambar 4. Respon Siswa

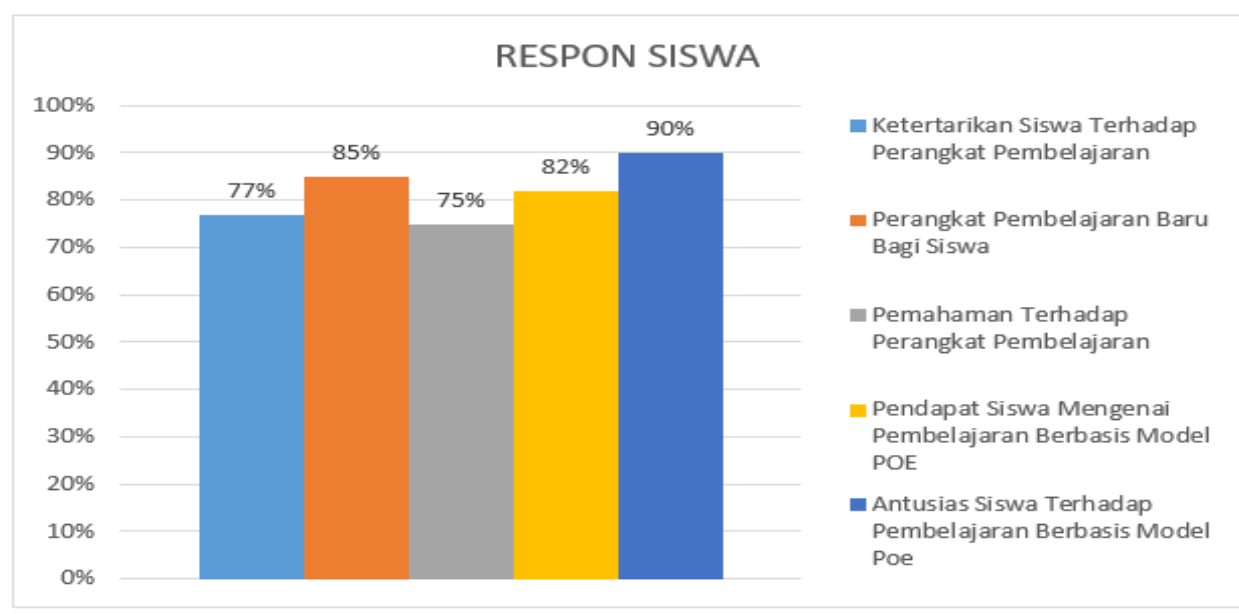

Data diatas telah membuktikan bahwa pembelajaran ini menarik untuk diterapkan karena dengan penggunaan model POE siswa menjadi lebih aktif di dalam kelas dan pembelajaran menjadi lebih interaktif sehingga siswa sangat antusias untuk mengikut pembelajaran selanjutnya.

Kefektivan dari perangkat pembelajaran dilihat dari ketuntasan tes hasil belajar yang dilakukan oleh siswa sebanyak 2 kali tes yaitu pre-test dan post-test, nilai dari kedua tes terbsebut nantinya akan dilihat ketuntasannya apabila nilai post-test meningkat setelah siswa mengikuti pembelajaran maka dapat dikatakan efektif. Tes keterampilan berpikir kritis yang digunakan beracuan pada indikator yang dijelaskan oleh Ennis (Susanto, 2013:125) yaitu: 1) siswa dapat melakukan penjelasan secara sederhana serta menganalisa argumen yang ia terima, 2) kemampuan dalam memiliki keterampilan dasar yang merupakan kemampuan untuk menentukan sumber-sumber yang relevan, 3) siswa dapat menyimpulkan yang berarti menentukan hasil dari pertimbangan yang dilakukan, 4) siswa dapat memberikan penjelasan lanjut yang berika mengidentifikasi asumsi dan mempertimbangkan suatu definisi dan 5) mengatur solusi/strategi. Berikut ini merupakan gambaran peningkatakan kemampuan berpikir kritis siswa pada saat penelitian.

Gambar 5. Perbandingan Tes Keterampilan Berpikir Kritis.

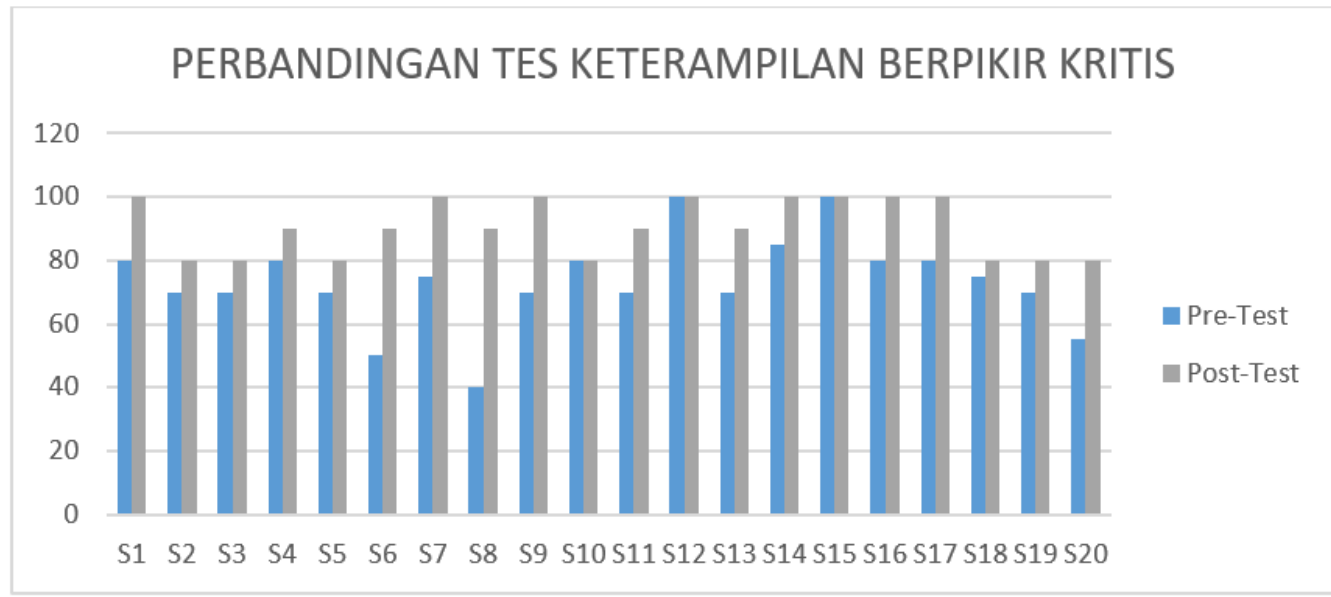

AL-MURABBI: Jurnal Studi Kependidikan dan Keislaman Vol. 7, No. 2 (2021) 
Data perolehan nilai pre-test dan post-test yang terdapat pada grafik di atas menunjukkan bahwa nilai siswa meningkat secaara drastis setelah mengikuti pembelajaran, hal tersebut menjelaskan bahwa pembelajaran yang telah dilakukan efektif. Pada hasil tes keterampilan berpikir kritis sebelum mengikuti pembelajaran terdapat 10 siswa yang mendapatkan nilai $\geq 75$ dengan presentase ketuntasan klasikal sebesar 50\% akan tetapi setelah mengikuti pembelajaran seluruh siswa mendapatkan nilai diatas $\geq 75$ dengan ketuntasan klasikal sebesar $100 \%$, sedangkan perolehan $\mathrm{N}$ gainnya termasuk dalam g-sedang dengan nilai rata-rata 0,57 . Berdasarkan data yang telah dipaparkan maka dapat ditarik kesimpulan bahwa perangkat pembelajaran berbasis model POE dapat merangsang siswa untuk meningkatkan kemampuan berpikir secara kritis yang ada pada dirinya.

Penilaian kefektivan tidak hanya melihat dari peningkatan nilai pada kemampuan berpikir kritis akan tetapi juga melihat peningkatan nilai pada tes yang berkaitan dengan pemahaman konsep siswa. Berikut ini grafik yang menunjukkan peningkatan pemahaman konsep siswa berdasarakan nilai sebelum dan sesudah melakukan pembelajaran.

Gambar 6. Perbandingan Tes Pemahaman Konsep

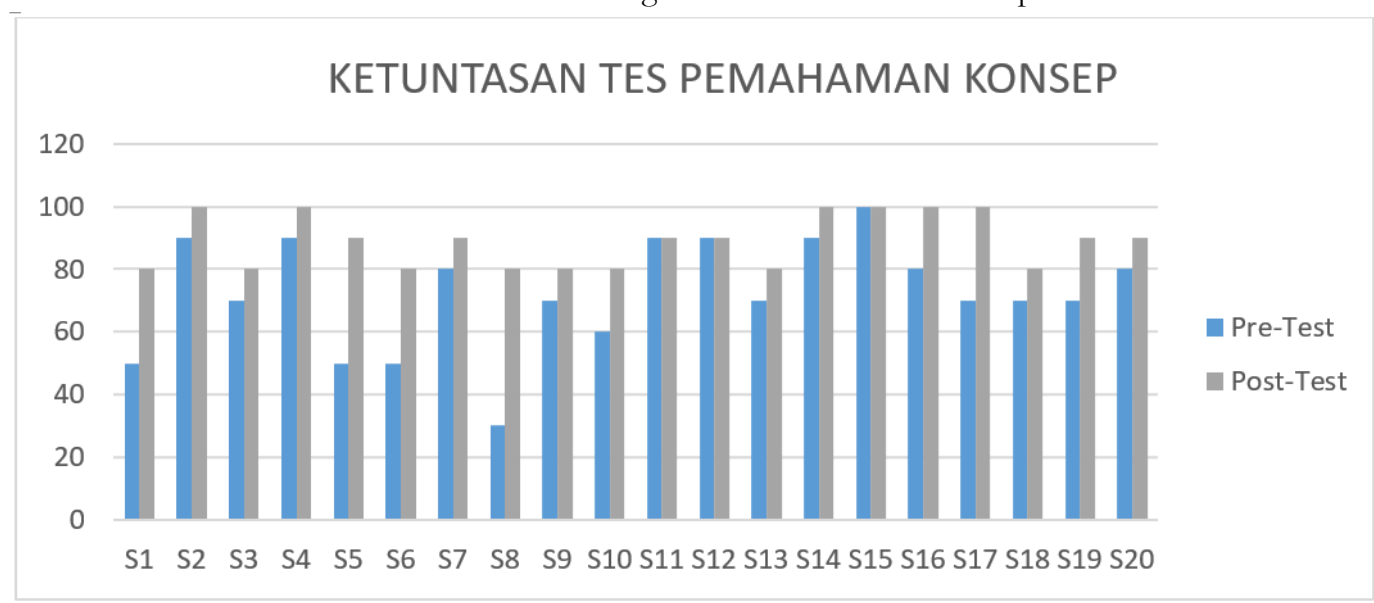

Data pada grafik di atas menujukkan bahwa kemampuan dalam memahami konsep pembelajaran yang dimiliki siswa mengalami peningkatan setelah mengikuti pembelajaran berbasis POE dibandingkan sebelum mengikuti pembelajaran. Pada data tersebut menunjukkan bahwa sebelum siswa melakukan pembelajaran hanya 9 orang siswa saja yang mendapatkan nilai diatas $\geq 75$ dengan ketuntasan klasikal sebesar 45\% dan telah siswa melakukan proses belajar berbasis model POE secara keseluruhan siswa memperoleh nilai di atas $\geq 75$ dengan ketuntasan klasikal sebesa 100\%. Sedangkan untuk perhitungan $\mathrm{N}$-gain yang telah dilakukan memiliki nilai rata-rata 0,56 (g-sedang). Berdasarkan data yang telah dianalisis tersebut maka bisa dikatakan bahwa proses pembelajaran berbasis model POE yang dilakukan siswa dapat membantu siswa untuk memahami konsep dari materi pembelajaran. 


\section{Catatan Akhir}

Rancangan proses pembelajaran yang telah dikembangkan dapat dikatakan memiliki kevalidan yang baik dan berdasarkan penilaian tersebut maka setiap komponen pembelajaran layak unutk diterapkan pada proses pembelajaran dikelas. Sedangkan untuk penerapannya dapat dikatakan baik, hal tersebut berdasarkan hasil pengamatan dan analisi terhadap uji coba produk perangkat pembelajaran yang dilakukan sebanyak 2 kali pertemuan dan memberikan hasil yang posiif, serta aktivitas siswa selama mengikuti pembelajaran yang tergolong aktif, dan respon yang ditunjukkan oleh siswa termasuk respon yang positif.

Kefektivan proses pembelajaran berbasis model POE dapat dikatakan efektif, hal tersebut dapat dibuktikan dari hasil tes yang diperoleh siswa setelah melakukan pembelajaran terdapat perbedaan yang sangat signifikan terhadap hasil tes keterampilan berpikir kritis dan pemahaman konsep siswa setelah mengikuti pembelajaran.

Pengembangan perangkat pembelajaran predict, observe, explain (POE) untuk meningkatkan keterampilan berpikir kritis dan pemahaman konsep siswa kelas $\mathrm{V}$ sekolah dasar telah diuji kelayakannya, keperaktisannya, dan keefektivannya. Disarankan kepada guru dan peneliti selanjutnya untuk: (1) menggunakna model POE pada setiap kali pembelajaran agar dapat melatih kemampuan berpikir secara kritis sehingga dapat membantu siswa dalam memahami konsep pembelajaran. (2) peneliti yang ingin mengkaji penerapan model POE dalam proses pembelajaran sebaiknya menggunakan variabel-variabel penelitian yang berbeda dan menggunakan materi yang berbeda agar dapat melihat efektivitas dari penerapan model POE pada materi pembelajaran lainnya.

\section{Daftar Rujukan}

Fisher, Alec. (2009). Berpikir Kritis Sebuah Pengantar. (Benyamin Hadinata, Penerjemah). UK: Cambridge University Press

Haryono, A. D. (2009). Metode Peraktis Pengembangan Sumber Belajar dan Media Pembelajaran. Malang: Genius Media

Hobri. (2010). Metodologi Penelitian Pengmbangan (Aplikasi Pada Penelitian Pendidikan Matematika). Jember: Pena Salsabila

Kala, N., Yaman F., \& Ayas, A. (2012). The Efectiviness of Predict-Observe-Explain Technique in Probling Stundent' Understanding About Acid-Base Chemistry: Ph, Poh, and Strength. Internationa Journal of Science and Mathematics Education, 11(3), 5557. Doi: 10.1007/s10763-012-9354-z

Risvaneli. (2017). Peningkatan Hasil Belajar dan Aktivitas Belajar Siswa Kelas V Menggunakan Pendekatan Value Clarification Technique (VCT) Pada Pembelajaran PKn di SDN 2 Batang Anai Kabupaten Padang Pariaman. Jurnal Penelitian Pendidikan Indonesia (JPPI). 3(2), -5. Doi: https://doi.org/10.29210//02017115.

Sriyanti (2019). Upara Meningkatkan Pemahaman Konsep Matematika Melalui Diskusi

Kelompok Berbantuan Alat Peraga. Jurnal Pendidikan Matematikan dan Ipa . 10(1). 63-73. Doi: 10.26418/Jpmipa.V10i1.2965 8

Sugiyono. (2015). Metode Penelitian Kuantitatif, Kualitatif, dan R\&D. Bandung: Alfabeta Sundayana, Rostina. (2014). Statistika Penelitian Pendidikan. Bandung: Alfabeta 
Dimas Aditya Nugroho, Mustaji, Raden Roro Nanik Setyowati, Pengembangan Perangkat

Suprijono, Agus. (2016a). Model-Model Pembelajaran Emansipatoris. Yogyakarta: Pustaka Pelajar

Susanto, Ahmad. (2013). Teori Belajar dan Pembelajaran di Sekolah Dasar. Jakarta: Pranamedia Group 